\title{
The Chuvash People of Kazakhstan: Dynamics of Quantity and Reasons of Migration
}

\section{Tatiana Titova}

\author{
PhD, Doctor in History, Full Professor, Kazan (Volga region) Federal University \\ tatiana.titova@rambler.ru
}

\section{Oksana Egorova}

PhD, Doctor in History, Associate Professor, Chuvash State University named after I.N. Ulyanov eoks71@rambler.ru

\section{Doi:10.5901/mjss.2015.v6n6s5p275}

\begin{abstract}
The relevance of the studied problem is caused by a steady tendency of reduction of Chuvash population on the territory of Kazakhstan. The purpose of this article consists in consideration of dynamics of Chuvash population on the territory of Kazakhstan in XX-XXI centuries. The leading approach to research of this problem is the complex analysis of the available sources and literature, as well as collecting and analysis of field material. The analysis of dynamics of Chuvash population on the territory of Kazakhstan where being in considerable isolation from the historical homeland, the Chuvash people keep ethnic consciousness and spiritual traditions of the people. Materials of the article can be useful to ethnographers, sociologists, culturologists, political scientists and other scientists, public representatives in their analytical work.
\end{abstract}

Keywords: migration, diaspora, population, identity.

\section{Introduction}

In 1939-1959 there was a sharp increase in a share and absolute number of the Chuvash people in the population of Kazakhstan. It was connected with development of a virgin soil and the corresponding mass resettlement of the Chuvash to Kazakhstan. The large-scale industrialization of Kazakhstan during the post-war period which caused inflow of labor from the European part of the USSR (Yagafova, 2013. P. 108) became the other factor of social and demographic transformations in the region. Mass departure of the Chuvash from Kazakhstan to Russia, in particular to the Chuvash Republic, began in the 90-ies after the collapse of the USSR. Following the results of the last national (general) population census of 2009 the number of the Chuvash people of Kazakhstan made 7,3 thousand people (the specific weight of 0,05\%) (Zhumasultanov, 2012. P. 99). By data for January 1, 2014 there were 6741 Chuvash (the specific weight of $0,04 \%)$. Thus, on the basis of studying of migrant processes and statistical data on the number of the Chuvash people living in the Republic of Kazakhstan it is possible to draw a conclusion on existence of a problem which is a steady tendency of reduction of number of the Chuvash living in Kazakhstan. The chronological scope is limited by the 90-ies of XX - the beginning of XXI centuries. Earlier data were also used in order to determine the dynamics Chuvash population in Kazakhstan.

\subsection{Practical importance}

The study of reasons of mass departure of the Chuvash to Russia in the 90-ies of the XX century and factors which have negative influence on the number of the Chuvash population of Kazakhstan today, have important scientific, cultural and political value for the Chuvash Republic and Russia. Identification of the processes resulting in system of the interethnic relations of the Republic of Kazakhstan, their interrelation with nature of relationship of Russia and Kazakhstan, the Chuvash Republic and Kazakhstan let us develop scientifically based recommendations for correction of national and migration policy in Chuvashia and Russia. Besides, there is an opportunity to predict the Chuvash population dynamics in Kazakhstan for several years. This work is especially significant now when at the federal level Russia established a new system developed for implementation of the national policy, which includes activity of the Federal agency on affairs of nationalities and organization of its interaction with the relevant regional executive authorities. 


\subsection{Hypothesis}

A preliminary study of the problem and historiography of the question let us formulate the following hypothesis. The major factors which have influence on migration of the Chuvash to Russia are: the state national policy which is represented in a form of limited opportunities for self-realization of diaspora members in various fields in comparison with the representatives of the title nation; different standards of living at the place of residence in Kazakhstan compared to their relatives and acquaintances in Russia; active implementation of "A state program on rendering assistance to voluntary resettlement of compatriots living abroad on the territory of the Russian Federation ". The forecast is as follows: first of all dynamics of the Chuvash population depends on the extent of influence of the factors stated above. Under invariable conditions in the next five years the number of the Chuvash people moving to Russia will not change.

\section{Research Methodology}

\subsection{Research problems}

For the purpose of the research the following problems have been solved: 1) the reasons of mass migration of the Chuvash to Kazakhstan in the Soviet period and the extent of influence of geopolitical processes in the former Soviet Union on migration of the Chuvash population in the 90-ies of the XX century have been identified; 2) the character and the extent of interactions of internal (national and religious) politics in Kazakhstan and the degree of comfort of accommodation for the Chuvash population have been determined; 3) the analysis of influence of the national policy of Russia and the Chuvash Republic on migration of the Chuvash population from Kazakhstan to Russia has been carried out; 4) the major factors having influence on dynamics and the number of the Chuvash population living in Kazakhstan and the number of the Chuvash people migrating to the Chuvash Republic have been determined; 5) the forecast of trends of migration of the Chuvash to Russia for the next 5 years has been made.

\subsection{Theoretical and empirical methods}

Some provisions of the theory of nationalism (Gellner, 2009; Hobsbawn, 1983), socialization (Berger \& Lukman, 1995; Barth, 1989), and the concept of "the social organization of cultural distinctions" of F. Bart (Bart, 2006) have been used as a basic approach.

A complex of various methods has been used in order to confirm the hypothesis:

- theoretical methods - the analysis of the published literature, normative and statistical data on the problem; summarizing of migration processes, analysis and synthesis.

- empirical methods including supervision for summarizing of available information on life of the Chuvash population in Kazakhstan. The information was gathered directly by carrying out a survey with a prepared questionnaire, and also during direct conversations. The quantitative (mathematical) methods were used for data processing. Thus we gathered core information, available for the discourse analysis.

\subsection{Research foundation}

The Houses of Friendship in Pavlodar and Almaty of the Republic of Kazakhstan became the research base.

\subsection{Research stages}

The research was conducted in three stages:

The first stage involved collecting and studying of official information on the number of the Chuvash living in Kazakhstan and implementation of the national migration policy in Russia, Kazakhstan and Chuvashia was carried out; we analyzed and generalized the published literature; updated addresses of Chuvash residents on the territory of Kazakhstan and the Chuvash migrants from Kazakhstan to Chuvashia.

The second stage included the field research: interviews with the Chuvash who moved from Kazakhstan to Chuvashia; field expeditions to the places of compact residence of the Chuvash in Kazakhstan;

The third stage included processing of field materials, generalization of the analyzed information, confirmation of the research hypothesis, formulation of conclusions (results) of the research. 


\section{Results and Discussion}

Kazakhstan holds a special position in Central Asia due to the poly-ethnicity of the population. Nowadays the representatives of more than a hundred nations live in the republic. The Assembly of the people of Kazakhstan and the regional House of friendship play an important role for implementation of the national policy. The Houses of Friendship have been built in all big cities of the republic and transferred to the possession of the national and cultural societies. These societies receive annual grants for teaching native languages, support of national traditions and development of arts. The year of 2015 has been declared as the year of the Assembly of the people of Kazakhstan which proves that this issue is significant. The research showed that such close attention and financial support of national and cultural societies aim at control of their activity and minimization of negative processes (discontent) in diasporas.

The share and the number of the Chuvash population of Kazakhstan increased double which was connected with the development of virgin lands and mass resettlement of the Chuvash in 1954-1960 in the east of Russia and Kazakhstan. The youth left for Kazakhstan with pleasure. Many girls considered it as the opportunity to leave their villages, to see new places and to get a passport. Those who were eager to leave in the 50-ies of the XX century had to address the district committees of Komsomol in order to obtain a permit. Many respondents noted that they "were running away" to follow their schoolmates or relatives. In Kazakhstan they mastered different professions as an assistant combine operator, cook, etc. The Chuvash from different regions of Russia met in Kazakhstan. Many girls, having got acquainted with guys, left Kazakhstan and settled in the home town of the husband. The Chuvash residents of Almaty arrived from Krasnoyarsk region, Kemerovo region and other Siberian areas. The city attracted them by the warm climate, gardens rich with apples, fertile soil and a beautiful landscape. The Chuvash cultural center was created in 1992 in Almaty, there were 1096 Chuvash. However it doesn't exist now.

It has been revealed by the author that modern Chuvash are generally concentrated in five areas of the republic: in Karaganda, Kostanay, Pavlodar, North Kazakhstan, and Aktyubinsk regions. According to the Committee on statistics of the Republic of Kazakhstan the number of Chuvash since 1970 in all areas of Kazakhstan is decreasing annually.

The total number of Chuvash population in 1970 was 22960 people, on January 01, $2014-6741$ people. The decrease of population is $70.3 \%$. As for the decrease of urban Chuvash in a period from 1999 till 2009 population it is almost proportional: the number of male population in decreased by $44.83 \%$, female population - by $41.38 \%$. Among the rural population the difference between the number of male and female population is less than in cities and equals $29.11 \%$ (male) and $30.62 \%$ (female).

Chuvash people regard their heritage with trepidation and try to keep their traditions. During the field study we found out the Chuvash people who live in rural areas or in houses with subsidiary small-holding in cities are more interested in their national traditions. People of this category mostly remember how they work in their parents' home and have an opportunity practice such activities as cattle and poultry breeding; they cook home-made beer and bake khoupla, etc.

Analyzing the age categories of the Chuvash we noted that according to the census of 2009 the largest number of Chuvash residents (1304 people) was among the age group of 50-59 y.o., in 19992038 people belonged to the age group of 40-49 y.o. We deal with people of the same generation represented by those who were born in 1950-1959people, who came to Kazakhstan with Komsomol permits in order to work on virgin lands and in coal mines. The research demonstrated that being at a distance from their historical homeland, the Chuvash keep ethnic consciousness and observe religious traditions of the people. When they were asked, what emotions arose when you heard news about Chuvashia, informants noted that their heart beat high, they said: "My homeland! The homeland", "I shiver when I hear about Chuvash", "Oh, my compatriots", "Everybody, come here, they show Chuvashia!".

Among the Chuvash population the higher education is in great demand. It is remarkable that there is a widespread opinion that the education level in the Russian Federation is better. Thus many Chuvash seek to send their children and grandchildren to Russian cities to get higher education (Omsk, Barnaul, Novosibirsk, etc.). Parents wish that their children after they graduate from Russian universities could remain to live in Russia.

With the collapse of the USSR the number of Chuvash started being reduced strongly; many of them came back to their historical homeland - to Chuvashia. The researchers usually name a number of socio-political and economic problems such as rapid demographic growth of the Kazakh population, migration of the rustic folk to the cities, strengthening of interethnic competition in labor markets, "indigenization" in a public service sector and the leading branches of economy, restrictions on speaking Russian, etc. as the main reasons for departure of the Chuvash and other Russian-speaking population. (Yagafova, 2013. P. 108-109). The Chuvash who have already returned home, remember good work and friendly relations in auls before the collapse of the USSR, but then a lot of things changed, first of all, they lost work, there they remained without means of support. The research showed that the major factors which led to the 
mass outflow of the Chuvash to Russia, were: rapid growth of nationalism in the 90-ies of the XX century; decrease in standards of living caused by the destruction of the economic relations operating in the USSR.

According to the Migration Service of the Chuvash Republic for January 1, 1996 the population of the republic numbers 2840 refugees and displaced persons, 2705 of them arrived from the neighboring countries, including 509 from Kazakhstan. The number of compelled migrants in 1994-1995 from Kazakhstan was high. And today some Chuvash of Kazakhstan try to return to their homeland. Compared with 2003 according to the date of January 01, 2015 the number of migrants to the Chuvash Republic has reduced to 21 times. It is connected with the decrease of number of Chuvash residents in Kazakhstan and a new place of residence of their relatives and more often children. Nearly a half of those who left Kazakhstan moved to their homeland. As noted above, those young people who got higher education in Russia try to get a job and settle down to married life at the new location.

In 2014 the Republic of Chuvashia joined the state program on rendering assistance to voluntary resettlement of compatriots living abroad in the Russian Federation. From June to December, 2014 they received 299 applications, 8 of them were from Kazakhstan. Today, unlike in the 90 -ies of the XX century, the problem of nationalism in Kazakhstan is not strongly expressed. However, the difference in opportunities for self-realization of Kazakhs and Chuvash is urgent. Especially it is noticeable in the field of public administration and business. The authority of a powerful clan has a great impact on the number of opportunities for Kazakhs. The second serious problem is the standard of living of Chuvash population, as it is low in comparison with the Russian Federation living standards in places of compact accommodation of the Chuvash diaspora. Reduction in number of the Chuvash people is also caused by mixed marriages. In the West Kazakhstan region, according to the national population census of 1999105566 monogamous and nuclear families were registered, $91368(86,6 \%)$ of them consists of the representatives of one nationality and $14198(13,4 \%)$ - of the representatives of two nationalities. The share of families consisting of the representatives of the Turkic ethnos is 1082 $(32,6 \%)$ families, where of Tatar origin - 847, Bashkir origin - 90, Azerbaijani origin - 50, Uzbek origin - 43, Kyrgyz origin -24 , Chuvash origin -18 , Uyghur origin -8 , Turk origin -2 (Kalysh, 2013. P. 341).

Thus, the number of the Chuvash population living in the Republic of Kazakhstan decreases every year. The Chuvash diaspora try to keep their culture, language, keep in contact with the Chuvash Republic. As a rule, such attitude is wide-spread among the elderly of the Chuvash diaspora which do not plan to change a place of residence. People under the age of retirement have a desire to move to the Russian Federation in order to retire when they are 55 years old, not 63 as in Kazakhstan. However the desire to get education in Russia and remain there is peculiar to young Chuvash. Especially it is noticeable in families which have low income. As a result all provisions of the hypothesis have been confirmed.

In research work of A.B. Kalysh, Kazakh scientist from Al-Farabi Kazakh National University the problems of family and marriage relations in mono - and multiethnic regions of Kazakhstan are considered (Kalysh, 2013). The study of diaspora groups is of a great interest for many researchers of Russia. Under the guidance of the leading ethnologist of the Republic of Tatarstan T.A. Titova we have already studied German (Titova, Bariyev, 2010) and Tatar population of Kazakhstan (Titova, Makhmutov, 2008; Makhmutov, 2011). The analysis of mixed marriages represents a special interest. Professor E.A. Yagafova studied the frequency of communication of diaspora with the ethnic environment in the region of residence and with the republic of Chuvashia, the influence of public organizations on the Chuvash "diaspora", the degree of their ethnic group compliance with the concept of "a classical diaspora" and their socio-cultural adaptation mechanisms in a new residential environment (Yagafova, 2013, 2015).

\section{Conclusion}

Materials of this article can be useful for ethnographers, sociologists, culturologists, political scientists and other scientists, as soon as the article contains practical materials and applicable conclusions made by the author. A complex of scientific, theoretical and practical activities was carried out in order to accomplish the task, such as analysis of scientific materials and periodicals, official documentation and statistics, information gathered during focus group discussions. The results of the research are significant for employees of public authorities on issues connected with development and implementation of domestic policy and problems of cooperation with the CIS countries including Kazakhstan. The conclusions of the research and the forecast of dynamics of number of the Chuvash population in Kazakhstan can be relevant for practical studies. The article will be useful for public representatives, including national and cultural associations of the Chuvash. The results of the research demonstrate a steady tendency to reduce the number of Chuvash population, both male and female. The population migrate from the Republic of Kazakhstan to the republic of Chuvashia and other regions of the Russian Federation. The proportion of mixed marriages among the Chuvash is gradually increasing. 


\section{Acknowledgments}

The work is performed according to the Russian Government Program of Competitive Growth of Kazan Federal University.

\section{References}

Berger, P.L., Lukman, T. (1995). The Social Construction of Reality: A Treatise on the Sociology of Knowledge. Academia-Center-Media, 323.

Bart, F. (2006). Etnicheskie gruppy i sotsialnye granitsy, Moskva.

Barth, F. (1998). Analysis of Culture in Complex Societies. Ethnos, 4, 120-142.

Gellner, E. (2009). Nations and Nationalism. Cornell University Press, 152.

Hobsbawn, E. (1983). Invention of Tradition. Cambridge University Press, 320.

Kalysh, A.B. (2013) Semya i brak v sovremennom Kazakhstane, Almaty: Aris.

Makhmutov, Z.A. (2011). K voprosu ob etnicheskoy identichnosti tatar Kazakhstana. Etnologicheskie issledovaniya v Tatarstane, edition 5. Kazan, 255-266.

Titova, T.A., Makhmutov, Z.A. (2008). Tatarskoe naselenie Severnogo Kazakhstana. Etnologicheskie issledovaniya v Respublike Kazakhstan, Kazan, 2008, 291-303.

Titova, T.A., Bariev, T.R. (2010). K voprosu ob etnicheskoy identichnosti nemetskogo naseleniya Severnogo Kazakhstana. Etnologicheskie issledovaniya v Tatarstane, Edition IV. Kazan, 250-254.

The Committee on statistics of the Republic of Kazakhstan Republic. http:// www.stat.gov.kz/faces/wcnav_externalld/homeNumbers Population?_afrLoop=62277532533969\#\%40\%3F_afrLoop\%3D62277532533969\%26_adf.ctrl-state\%3D6r2j9h6xu_58 (March 4, 2015).

Yagafova, E.A. (2013). Chuvashskaya diaspora na post-sovetskom prostranstve. Samara: PGSGA.

Zhumasultanov, T.Zh. (2012). Sotsialno-etnicheskaya struktura naseleniya sovremennogo Kazakhstana. Ekonomika i statistika, № 4, 94-102. 